\title{
Effectiveness of salicylic acid, Pseudomonas fluorescens CHAO and Trichoderma viride to control Meloidogyne incognita race 2 on different tomato cultivars
}

\author{
L. Esfahani', S. Jamali ${ }^{*}$, A. Saeedizadeh ${ }^{2}$ and H. Pedramfar'
}

Summary The effects of salicylic acid (SA), Trichoderma viride and Pseudomonas fluorescens CHAO were studied on the root-knot nematode Meloidogyne incognita race 2 in resistant and susceptible tomato cultivars (Gina VF, Falat CH, Falat 111, Karoon) during 2012-2013. Four-leaf tomato seedlings were used, grown in pots containing $1000 \mathrm{~g}$ of sterilized soil; each seedling receiving $20 \mathrm{ml}$ of T. viride suspension containing $1 \times 10^{6}$ spores, $30 \mathrm{ml}$ of $P$. fluorescens CHA0 with $10^{9} \mathrm{cfu} / \mathrm{ml}, 5 \mathrm{mM}$ of salicylic acid and 2000 second stage nematode juveniles. Parameters relevant to nematode population and plant growth were evaluated. The biocontrol agents and salicylic acid were effective in nematode control in combined and single treatments. High reductions in root galling and egg mass indices were observed with combination of SA and biocontrol agents. The greatest increase in plant growth was obtained when cv. Falat $\mathrm{CH}$ was treated with SA followed by $P$. fluorescens $\mathrm{CHAO}$ and T. viride. The highest number of galls was recorded in cv. Karoon, followed by cvs. Falat 111, Gina VF and Falat CH. Pseudomonas fluorescens $\mathrm{CHAO}$ provoked the highest increase in fresh and dry root weight, fresh and dry shoot weight and plant length in all free nematode treatments. The results indicated that chemical inducer (salicylic acid), in combination with biocontrol agents ( $T$. viride and P. fluorescens CHAO), stimulated and eventually increased plant growth.

Additional keywords: biocontrol, Lycopersicon esculentum, reproduction factor, root-knot nematode

\section{Introduction}

Root knot nematodes are one of the most important plant parasites. They have a wide host range including more than 2000 plant species (Gugino et al., 2008). The primary symptom of root-knot nematode infection is the formation of typical root galls on the roots of susceptible host plants. Nutrient and water uptake are substantially reduced because of the damaged root system, resulting in weak and low-yielding plants (Abad et al., 2003). Meloidogyne spp. can severely damage important crops including tomato, cucumber and melon in many areas. The nematodes are major pests on tomatoes causing considerable yield losses (Sahebani and Ha-

\footnotetext{
1 Department of Plant Protection, Faculty of Agricultural Sciences, University of Guilan, P.O. Box: 41635-1314, Rasht, Iran

2 Faculty of Agriculture, Shahed University, P.O. Box: 33191-18651, Tehran, Iran

* Corresponding author: Jamali_s2002@yahoo.com
}

davi, 2008).

Biological control is a safe alternative to pesticides for phytonematode management, likely to be free from toxic residual effects. There are numerous microbial antagonists of root-knot nematodes and their application results in significant decrease in the nematode populations (Khan et al., 2007). In fact, a wide range of bacteria (Hallmann et al., 2001) and fungal agents (Meyer et al., 2001) have been used to reduce damages of plant parasitic nematodes. Pseudomonas fluorescens $\mathrm{CHAO}$ is a root-colonizing biocontrol bacterium that protects several plant species from root diseases caused by soil-borne fungi and root-knot nematodes (Siddiqui and Shaukat, 2002). Some species of Trichoderma spp. have widely been used as biocontrol agents against soil-borne plant diseases (Whipps, 2001) and root-knot nematodes (Sharon et al., 2001). Nandy et al. (2003) found that salicylic acid decreased gall and egg numbers of Meloidogyne incognita on okra and cowpea. Numerous studies have separately inves- 
tigated the impact of biocontrol agents to control root-knot nematodes on susceptible cultivars. However, comprehensive research about the effects of salicylic acid (SA), Trichoderma and Pseudomonas simultaneously on $M$. incognita race 2 in both susceptible and resistance tomato cultivars has not yet been implemented. The present study examined the effect of a chemical inducer (SA) and two biocontrol agents ( $T$. viride and $P$. fluorescens CHAO), when used independently and in combination, in controlling $M$. incognita race 2 on different tomato cultivars.

\section{Materials and Methods}

\section{Nematode Inocula}

Infected root samples were collected from naturally infested tomato plants in a greenhouse. Roots were rinsed with water and nematodes were extracted from egg masses present on the galled tissue. The identification of the root-knot nematode species was based on the shape of the perineal pattern (Jepson 1987) according to the methods of Taylor and Netscher (1974). The races of root-knot nematode populations were identified on the basis of differential hosts tests (Hartman and Sasser, 1985). A single egg mass was used to establish a population on tomato plants. Eggs were extracted from galled tomato roots using 1.5\% $\mathrm{NaOCl}$ (Hussey and Barker, 1973), collected on a $25 \mu \mathrm{m}$ mesh sieve and transferred to a beaker containing distilled water. Hatched juveniles of $M$. incognita were obtained by placing the eggs in sterile distilled water for 5 days at $28 \pm 2^{\circ} \mathrm{C}$. The activities of juveniles were evaluated under a stereomicroscope.

\section{Biocontrol Agents}

Trichoderma viride and $P$. fluorescens $\mathrm{CHAO}$ were a kind offer of the Plant Pathology Department, Faculty of Agriculture, Shahed University. T. viride was cultured on potato dextrose agar (PDA) containing $150 \mathrm{mg}$ $\mathrm{I}^{-1}$ streptomycin and $150 \mathrm{mg} \mathrm{l}^{-1}$ of chloramphenicol, and was kept at $25^{\circ} \mathrm{C}$. The mycelia and formed conidia were carefully scraped from the media and suspended in $100 \mathrm{ml}$ of distilled water. Spores were separated from mycelia by sieving through a $50 \mu \mathrm{m}$ sieve. The spore suspensions were then adjusted to the desired concentration after counting spore density using a haemocytometer (Sahebani and Hadavi, 2008).

The bacterium isolate was stored in sterile distilled water and was cultured in nutrient agar medium. Density of $10^{9}$ colony forming unit (cfu) per milliliter of water of $24 \mathrm{~h}$ bacterium culture was prepared by serial dilution $\left(10^{1}-10^{9}\right)$ in $590 \mathrm{~nm}$ (Zhang et al., 2002).

\section{Chemical Agent}

Salicylic acid (SA) (Merck) was prepared and dissolved in ethanol and water in concentrations of $5 \mathrm{mM}$. Firstly, the necessary amounts of SA $(0.69 \mathrm{~g})$ were dissolved in 100 $\mathrm{ml} 96 \%$ methanol solution. The volume of the solution was brought to one liter with distilled water. Then, the concentration of $5 \mathrm{mM}$ was used and sprayed on the leaves (Zhang et al., 2002).

\section{Plant Cultures}

The tolerant tomato cultivars Gina VF, Falat 111 and the susceptible Falat $\mathrm{CH}$ and Karoon were used (Gharabadiyan et al., 2012). Seeds were sown in the pots containing $1000 \mathrm{~g}$ of sterilized mixture of field soil, leaf compost and sand at the rate of 1:1:2 in $24-27^{\circ} \mathrm{C}$ under greenhouse conditions. Three-week-old (four-leaf stage) seedlings were used in the experiments. The seedlings were inoculated with $T$. viride, $P$. fluorescens and salicylic acid, separately and jointly. Each seedling received $20 \mathrm{ml}$ of a liquid suspension of $T$. viride containing $1 \times 10^{6}$ spores, $30 \mathrm{ml}$ of bacterial suspension $10^{9}$ $\mathrm{cfu} / \mathrm{ml}$ and lastly $5 \mathrm{mM}$ salicylic acid. Four replicates were maintained for each treatment. The biocontrol agents were used by soil drenching, but SA was applied with foliar spray. The next day, $2000 \mathrm{~J}_{2}$ (two stage juveniles) of root-knot nematode per plant were used for the artificial inoculation. The inoculum was injected into 3 holes approximately $2 \mathrm{~cm}$ deep around the stem base. 
Forty five days after inoculation, nematode infestations as well as plant growth parameters were assessed. Two control sets were included, namely uninoculated and artificially inoculated plants with nematodes. The uninoculated control did not receive nematodes and biocontrol agents and SA and the inoculated control received only nematodes. The experiment consisted of 12 treatments: 1) non-inoculated (negative control); 2) only nematode (positive control); 3) $\mathrm{T}$ (Trichoderma); 4) $\mathrm{SA}$; 5) $\mathrm{P}$ (Pseudomonas); 6) $\mathrm{N}+\mathrm{T}$; 7) $\mathrm{N}+\mathrm{SA}$; 8) $\mathrm{N}+\mathrm{P}$; 9) $\mathrm{N}+\mathrm{T}+\mathrm{SA}$; 10) $\mathrm{N}+\mathrm{P}+\mathrm{SA}$; 11) $\mathrm{N}+\mathrm{P}+\mathrm{T}$; 12) $\mathrm{N}+\mathrm{P}+\mathrm{T}+\mathrm{SA}$. At harvest, roots were removed, washed free of soil and stained by $0.015 \%$ Phloxine B for 20 minutes to facilitate egg mass counting. The number of galls, egg masses per plant and length, fresh and dry weight of plants and nematode population in the soil were measured and recorded (Hussey and Janssen, 2002).

During the experiment, tomato plants were maintained in a greenhouse randomizing the position of the blocks and, at the same time, repositioning each plant within a block every week to avoid a block position effect and the factor 'position of the plant within the block'.

\section{Statistical Analysis}

The experimental design was factorial randomized complete block with 4 tomato cultivars, 12 treatments and 4 replications per treatment. The experiment was repeated for two years (2012 and 2013) under the same conditions. Statistical analysis proved that there was no statistically significant difference between the two years in recorded data and hence the results of two years were pooled. Comparison of the means was performed by ANOVA and Tukey test $(P \leq 0.01)$. According to Oostenbrinks equation [Oostenbrink, 1966], reproduction factor was calculated for each of the treatments based on $\mathrm{R}=\mathrm{PF} / \mathrm{PI}$ formula where $\mathrm{PI}$ is the initial population and PF is the final population. The Final Population density (PF) was obtained by counting second stage juvenile $\left(\mathrm{J}_{25}\right)$ population in the soil. All data was analyzed by SAS
Software Version 9.00.

\section{Results}

Detailed observations of $(n=10-20)$ female nematodes indicated that the perineal pattern characteristics and differential host tests correspond to Meloidogyne incognita race 2.

The data presented in Table 1 revealed that the combined inoculation of $T$. viride and $P$. fluorescens and SA improved the tomato plants' growth characters compared to the inoculated control.

According to Figure 1, the soil application of biocontrol agents and chemical inducer significantly $(P \leq 0.01)$ reduced galling and egg mass production compared to the inoculated control. Treatment 12 (soil drenching of biocontrol agents + foliar spray of SA) exhibited the lowest number of galls and egg masses compared to positive control and other treatments (Figure 1, Figure 2). Application of SA was also found to be effective against the nematode but less effective than $T$. viride and $P$. fluorescens (Figure 1). The greatest numbers of galls were recorded in the inoculated control pots of tomato cv. Karoon, followed by cvs. Falat 111, Gina VF and Falat $\mathrm{CH}$. (Figure 1). Egg masses at all treatments were significantly $(P \leq 0.01)$ different compared to the control. There were differences between the four tomato cultivars (Figure 2). Reproduction factor of $M$. incognita race 2 on the cultivars is shown in Figure 3.

The results showed that inoculation with the root-knot nematode caused significant reductions $(\mathrm{P} \leq 0.01)$ in fresh weight of roots $(23 \%, 30 \%, 27 \%$ and $49 \%)$, fresh weight of shoots $(45 \%, 51 \%, 48 \%$ and $54 \%)$, plant length $(25 \%, 31 \%, 34 \%$ and $27 \%)$, dry weight of shoots $(40 \%, 51 \%, 47 \%$ and $53 \%)$ and dry weight of roots (24\%, $48 \%, 26 \%$ and $41 \%)$, in the tomato cultivars Gina VF, Falat $\mathrm{CH}$, Falat 111 and Karoon, respectively, in comparison to the uninoculated control. The data presented in Table 1 revealed that the treatment of the soil with the biocontrol agents or salicylic acid without nematodes significantly increased plant growth parameters. 
Table 1. Effects of salicylic acid, Trichoderma viride and Pseudomonas fluorescens on growth parameters of four tomato cultivars (pooled data) infested with Meloidogyne incognita. C: uninoculated (negative control), N: Nematode (positive control), T: Trichoderma viride, SA: Salicylic acid, P: Pseudomonas fluorescens. Each value is the mean of four replicates in 2012 and 2013.

\begin{tabular}{|c|c|c|c|c|c|c|}
\hline \multirow{2}{*}{$\begin{array}{l}\text { Tomato } \\
\text { cultivar }\end{array}$} & \multirow{2}{*}{ Treatments } & \multirow{2}{*}{$\begin{array}{l}\text { Plant length } \\
(\mathrm{cm})\end{array}$} & \multicolumn{2}{|c|}{ Fresh weight (g) } & \multicolumn{2}{|c|}{ dry weight (g) } \\
\hline & & & Shoot & Root & Shoot & Root \\
\hline \multirow{11}{*}{ Gina VF } & $\stackrel{C}{N}$ & $\begin{array}{c}50.5 \pm 0.57 \\
37.75^{*} \pm 0.50\end{array}$ & $\begin{array}{l}51.3 \pm 0.31 \\
28.1^{*} \pm 0.12\end{array}$ & $\begin{array}{c}10.44 \pm 0.10 \\
8^{*} \pm 0.08\end{array}$ & $\begin{array}{l}10.27 \pm 0.32 \\
6.07 * \pm 0.10\end{array}$ & $\begin{array}{l}2.23 \pm 0.31 \\
1.58^{*} \pm 0.03\end{array}$ \\
\hline & $\mathrm{T}$ & $52.75 \pm 1.70$ & $53 \pm 1.41$ & $10.82 \pm 0.21$ & $10.7 \pm 0.47$ & $2.83^{*} \pm 0.11$ \\
\hline & SA & $54 \pm 2.16$ & $53.25 \pm 1.5$ & $10.75 \pm 0.29$ & $10.89 \pm 0.74$ & $2.65^{*} \pm 0.04$ \\
\hline & $\mathrm{P}$ & $55.75 \pm 2.5$ & $55 \pm 2.44$ & $11^{*} \pm 0.0816$ & $11.16 \pm 1.06$ & $2.92 * \pm 0.04$ \\
\hline & $\mathrm{N}+\mathrm{T}$ & $40^{*} \pm 2.94$ & $34.5^{*} \pm 0.57$ & $7.90^{*} \pm 0.08$ & $7.04^{*} \pm 0.65$ & $1.42^{*} \pm 0.04$ \\
\hline & $N+S A$ & $41^{*} \pm 2.16$ & $36^{*} \pm 0.81$ & $7.01^{*} \pm 0.11$ & $7.32^{*} \pm 0.25$ & $1.25^{*} \pm 0.04$ \\
\hline & $N+P$ & $44.25^{*} \pm 2.62$ & $40.75^{*} \pm 1.70$ & $8.15^{*} \pm 0.12$ & $8.28 \pm 0.94$ & $1.69^{*} \pm 0.03$ \\
\hline & $\mathrm{N}+\mathrm{T}+\mathrm{SA}$ & $50.25 \pm 0.50$ & $49.5 \pm 1.73$ & $10.05^{*} \pm 0.03$ & $10.02 \pm 0.76$ & $2.01 \pm 0.01$ \\
\hline & $\mathrm{N}+\mathrm{P}+\mathrm{SA}$ & $50.25 \pm 0.5$ & $50.5 \pm 1.29$ & $10.28 \pm 0.06$ & $10.19 \pm 1.1$ & $2.09 \pm 0.02$ \\
\hline & $\begin{array}{l}\mathrm{N}+\mathrm{P}+\mathrm{T} \\
\mathrm{N}+\mathrm{P}+\mathrm{T}+\mathrm{SA}\end{array}$ & $\begin{array}{l}52.5 \pm 0.57 \\
53.5 \pm 0.57\end{array}$ & $\begin{array}{c}50.75 \pm 0.95 \\
51.5 \pm 0.57\end{array}$ & $\begin{array}{l}10.1 \pm 0.081 \\
10.35 \pm 0.07\end{array}$ & $\begin{array}{l}10.29 \pm 0.73 \\
10.45 \pm 0.52\end{array}$ & $2.07 \pm 0.01$ \\
\hline & 然 & & & & & \\
\hline \multirow{10}{*}{ Falat $\mathrm{CH}$} & $\begin{array}{l}\mathrm{C} \\
\mathrm{N}\end{array}$ & $\begin{array}{c}53.5 \pm 0.57 \\
36.75^{*} \pm 0.50\end{array}$ & $\begin{array}{c}24.80 \pm 0.32 \\
12^{*} \pm 0.81\end{array}$ & $\begin{array}{c}8.61 \pm 0.13 \\
6^{*} \pm 0.08\end{array}$ & $\begin{array}{l}5.78 \pm 0.33 \\
2.8^{*} \pm 0.78\end{array}$ & $\begin{array}{c}2.01 \pm 0.01 \\
1.03^{*} \pm 0.02\end{array}$ \\
\hline & $\mathrm{T}$ & $57.5 \pm 2.08$ & $28.80 * \pm 0.37$ & $8.88 \pm 0.07$ & $6.73 \pm 1.08$ & $2.29 \pm 0.03$ \\
\hline & SA & $58.5 \pm 2.88$ & $29.41 * \pm 0.69$ & $8.75 \pm 0.23$ & $6.9 \pm 0.85$ & $2.11 \pm 0.01$ \\
\hline & $\mathrm{P}$ & $60 \pm 2.82$ & $33.06 * \pm 0.67$ & $9.04 * \pm 0.03$ & $7.76^{*} \pm 1.60$ & $2.43 \pm 0.05$ \\
\hline & $\mathrm{N}+\mathrm{T}$ & $40^{*} \pm 1.41$ & $16.16^{*} \pm 0.39$ & $5.79^{*} \pm 0.17$ & $3.86 \pm 0.17$ & $1.01^{*} \pm 0.08$ \\
\hline & $\mathrm{N}+\mathrm{SA}$ & $43^{*} \pm 2.94$ & $17.34^{*} \pm 1.14$ & $5.81 * \pm 0.16$ & $4.01 \pm 0.74$ & $0.98^{*} \pm 0.01$ \\
\hline & $\mathrm{N}+\mathrm{P}$ & $46^{*} \pm 1.63$ & $19.43^{*} \pm 2.20$ & $6.3^{*} \pm 0.216$ & $4.58 \pm 0.98$ & $1.06^{*} \pm 0.02$ \\
\hline & $\mathrm{N}+\mathrm{T}+\mathrm{SA}$ & $53 \pm 0.81$ & $24.55 \pm 0.54$ & $8^{*} \pm 0.01$ & $5.76 \pm 0.59$ & $1.4^{*} \pm 0.05$ \\
\hline & $\mathrm{N}+\mathrm{P}+\mathrm{SA}$ & $54 \pm 1.63$ & $23.34 \pm 1.08$ & $8.2 \pm 0.08$ & $5.47 \pm 0.36$ & $1.55^{*} \pm 0.42$ \\
\hline & $\begin{array}{l}\mathrm{N}+\mathrm{P}+\mathrm{T} \\
\mathrm{N}+\mathrm{P}+\mathrm{T}+\mathrm{SA}\end{array}$ & $\begin{array}{c}54.5 \pm 1.73 \\
55.5 \pm 2\end{array}$ & $\begin{array}{l}24.45 \pm 0.39 \\
25.00 \pm 1.96\end{array}$ & $\begin{array}{c}8.01 * \pm 0.02 \\
8.5 \pm 0.31\end{array}$ & $\begin{array}{l}5.76 \pm 0.37 \\
5.91 \pm 0.81\end{array}$ & $\begin{array}{c}1.42^{*} \pm 0.24 \\
1.96 \pm 0.06\end{array}$ \\
\hline \multirow{10}{*}{ Falat 111} & $\begin{array}{l}\mathrm{C} \\
\mathrm{N}\end{array}$ & $\begin{array}{l}48.25 \pm 0.50 \\
31.75^{*} \pm 0.50\end{array}$ & $\begin{array}{c}29.17 \pm 1.66 \\
15^{*} \pm 0.81\end{array}$ & $\begin{array}{l}9.82 \pm 0.04 \\
7.15^{*} \pm 0.12\end{array}$ & $\begin{array}{c}9.85 \pm 0.40 \\
5.13^{*} \pm 0.22\end{array}$ & $\begin{array}{c}2.15 \pm 0.02 \\
1.59^{*} \pm 0.15\end{array}$ \\
\hline & $\mathrm{T}$ & $51 \pm 2.16$ & $31.73 \pm 2.66$ & $10.04 \pm 0.03$ & $10.85 \pm 0.44$ & $2.19 \pm 0.03$ \\
\hline & SA & $52 \pm 1.63$ & $32.78 \pm 0.76$ & $9.94 \pm 0.12$ & $11.23 \pm 0.71$ & $2.17 \pm 0.02$ \\
\hline & $P$ & $55 \pm 0.81$ & $35.92^{*} \pm 2.84$ & $10.15^{*} \pm 0.13$ & $12.25^{*} \pm 0.94$ & $2.23^{*} \pm 0.02$ \\
\hline & $\mathrm{N}+\mathrm{T}$ & $38.25^{*} \pm 0.95$ & $19.53^{*} \pm 1.92$ & $6.94^{*} \pm 0.05$ & $6.75^{*} \pm 1.08$ & $1.56^{*} \pm 0.04$ \\
\hline & $N+S A$ & $39.25^{*} \pm 1.70$ & $20.33^{*} \pm 1.55$ & $6.45^{*} \pm 0.10$ & $6.98^{*} \pm 0.14$ & $1.46^{*} \pm 0.05$ \\
\hline & $N+P$ & $43^{*} \pm 2.16$ & $23.05^{*} \pm 1.51$ & $7.33^{*} \pm 0.17$ & $7.94 \pm 1.17$ & $1.65^{*} \pm 0.04$ \\
\hline & $\mathrm{N}+\mathrm{T}+\mathrm{SA}$ & $46 \pm 0.81$ & $28.97 \pm 0.57$ & $9.19^{*} \pm 0.11$ & $9.91 \pm 0.34$ & $2.02 * \pm 0.03$ \\
\hline & $\mathrm{N}+\mathrm{P}+\mathrm{SA}$ & $48.5 \pm 1.29$ & $28.78 \pm 1.63$ & $9.32 * \pm 0.04$ & $9.88 \pm 0.39$ & $2.05 \pm 0.06$ \\
\hline & $\begin{array}{l}\mathrm{N}+\mathrm{P}+\mathrm{T} \\
\mathrm{N}+\mathrm{P}+\mathrm{T}+\mathrm{SA}\end{array}$ & $\begin{array}{c}49.25 \pm 1.70 \\
52 \pm 1.63\end{array}$ & $\begin{array}{c}29.6 \pm 0.29 \\
30.02 \pm 0.29\end{array}$ & $\begin{array}{l}9.18^{*} \pm 0.01 \\
9.69 \pm 0.01\end{array}$ & $\begin{array}{l}10.26 \pm 0.87 \\
10.31 \pm 0.55\end{array}$ & $\begin{array}{c}2.02^{*} \pm 0.04 \\
2.13 \pm 0.02\end{array}$ \\
\hline \multirow{10}{*}{ Karoon } & $\begin{array}{l}\mathrm{C} \\
\mathrm{N}\end{array}$ & $\begin{array}{c}44.5 \pm 0.57 \\
32.25^{*} \pm 1.70\end{array}$ & $\begin{array}{c}23.97 \pm 2.53 \\
11^{*} \pm 0.81\end{array}$ & $\begin{array}{l}4.27 \pm 0.17 \\
2.15^{*} \pm 0.12\end{array}$ & $\begin{array}{c}11.2 \pm 0.46 \\
5.21^{*} \pm 0.16\end{array}$ & $\begin{array}{c}1.05 \pm 0.11 \\
0.61^{*} \pm 0.08\end{array}$ \\
\hline & $\mathrm{T}$ & $47.75 \pm 1.25$ & $24.95 \pm 1.34$ & $4.48 \pm 0.12$ & $11.82 \pm 0.85$ & $1.09 \pm 0.04$ \\
\hline & SA & $48.5 \pm 0.57$ & $25.01 \pm 2.13$ & $4.34 \pm 0.12$ & $11.95 \pm 1.36$ & $1.05 \pm 0.03$ \\
\hline & $P$ & $51.25 \pm 0.5$ & $27.22^{*} \pm 1.63$ & $4.65^{*} \pm 0.129$ & $12.87^{*} \pm 1.16$ & $1.11 \pm 0.06$ \\
\hline & $\mathrm{N}+\mathrm{T}$ & $38^{*} \pm 0.81$ & $15^{*} \pm 0.81$ & $2.26^{*} \pm 0.12$ & $7.28^{*} \pm 0.97$ & $0.64^{*} \pm 0.26$ \\
\hline & $\mathrm{N}+\mathrm{SA}$ & $39 * \pm 0.81$ & $16.88^{*} \pm 0.73$ & $2.15^{*} \pm 0.10$ & $7.60 * \pm 0.36$ & $0.61^{*} \pm 0.12$ \\
\hline & $N+P$ & $40^{*} \pm 2.16$ & $19.29^{*} \pm 0.54$ & $3.14^{*} \pm 0.12$ & $9.13 \pm 0.69$ & $0.82 \pm 0.10$ \\
\hline & $\mathrm{N}+\mathrm{T}+\mathrm{SA}$ & $41 \pm 2.16$ & $21.85 \pm 1.30$ & $3.99 \pm 0.01$ & $10.37 \pm 0.88$ & $0.99 \pm 0.03$ \\
\hline & $\mathrm{N}+\mathrm{P}+\mathrm{SA}$ & $44 \pm 0.81$ & $22.43 \pm 0.40$ & $4.15 \pm 0.07$ & $10.63 \pm 0.20$ & $1.03 \pm 0.02$ \\
\hline & $\begin{array}{l}\mathrm{N}+\mathrm{P}+\mathrm{T} \\
\mathrm{N}+\mathrm{P}+\mathrm{T}+\mathrm{SA}\end{array}$ & $\begin{array}{c}44.75 \pm 0.95 \\
45.5 \pm 0.57\end{array}$ & $\begin{array}{l}23.47 \pm 1.44 \\
24.10 \pm 1.89\end{array}$ & $\begin{array}{l}4.03 \pm 0.02 \\
4.19 \pm 0.12\end{array}$ & $\begin{array}{l}11.15 \pm 0.84 \\
11.43 \pm 0.47\end{array}$ & $\begin{array}{c}1 \pm 0.07 \\
1.04 \pm 0.10\end{array}$ \\
\hline
\end{tabular}

* Values are significantly different from the control (Tukey test, $\mathrm{P} \leq 0.01$ ). 


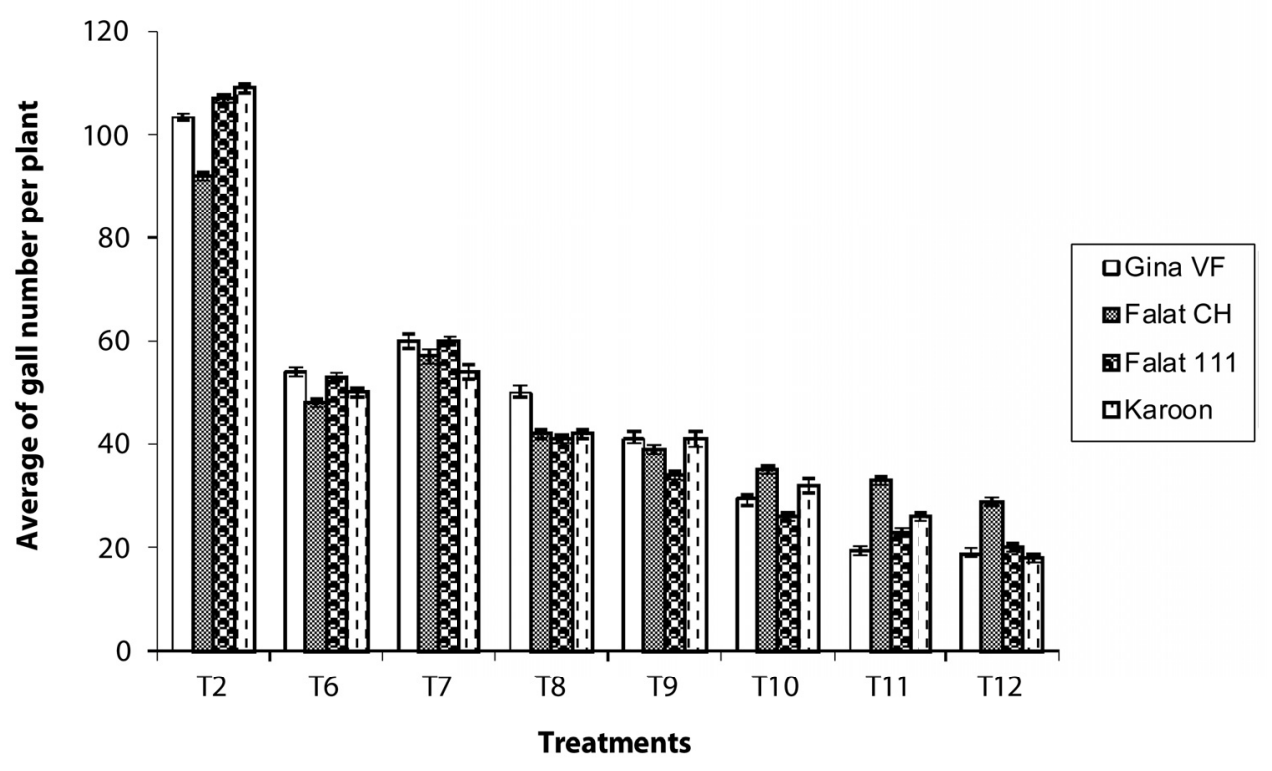

Figure 1. Mean gall numbers of Meloidogyne incognita/plant on the roots of four tomato cultivars (pooled data) treated with salicylic acid, Trichoderma viride and Pseudomonas fluorescens (Treatments: T2: $\mathrm{N}, \mathrm{T6}: \mathrm{N}+\mathrm{T}, \mathrm{T7}: \mathrm{N}+\mathrm{SA}, \mathrm{T8}: \mathrm{N}+\mathrm{P}, \mathrm{T}$ : $\mathrm{N}+\mathrm{T}+\mathrm{SA}, \mathrm{T10}: \mathrm{N}+\mathrm{P}+\mathrm{SA}, \mathrm{T} 11: \mathrm{N}+\mathrm{P}+\mathrm{T}, \mathrm{T12}: \mathrm{N}+\mathrm{P}+\mathrm{T}+\mathrm{SA}$; N: Nematode, T: Trichoderma viride, SA: Salicylic acid, P: Pseudomonas fluorescens). Each number is a mean of four replications in two years.

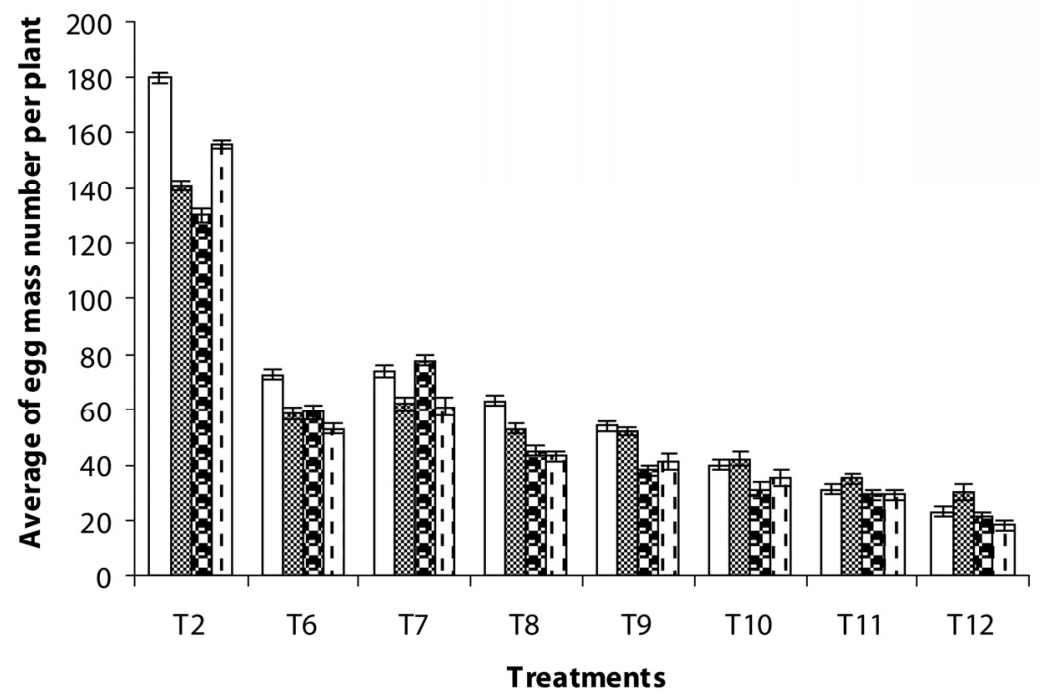

Figure 2. Mean egg mass number of Meloidogyne incognita/plant on the roots of four tomato cultivars (pooled data) treated with salicylic acid, Trichoderma viride and Pseudomonas fluorescens (Treatments: T2: N, T6: N+T, T7: N+SA, T8: N+P, T9: $\mathrm{N}+\mathrm{T}+\mathrm{SA}, \mathrm{T} 10: \mathrm{N}+\mathrm{P}+\mathrm{SA}$, T11: N+P+T, T12: N+P+T+SA; N: Nematode, T: Trichoderma viride, SA: Salicylic acid, P: Pseudomonas fluorescens). Each number is a mean of four replications in two years.

() Benaki Phytopathological Institute 


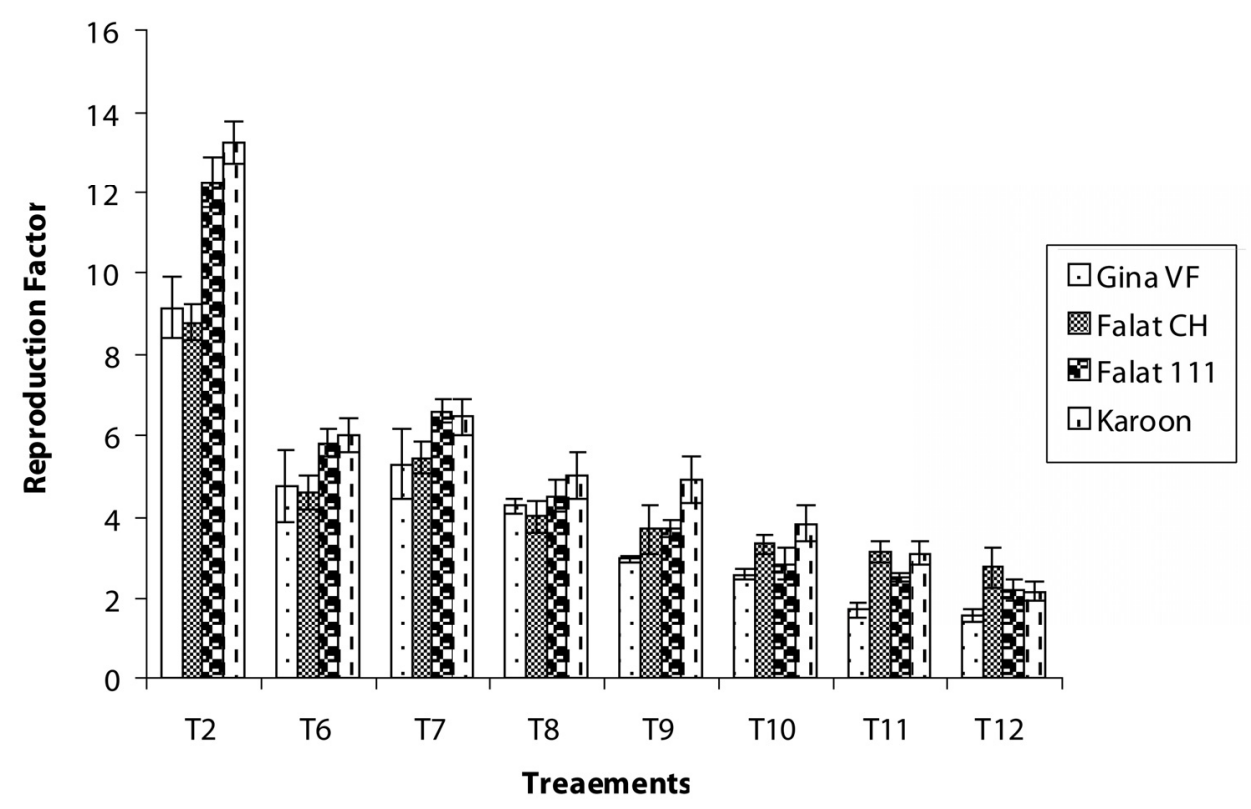

Figure 3. Reproduction factor of Meloidogyne incognita on the roots of four tomato cultivars (pooled data) treated with salicylic acid, Trichoderma viride and Pseudomonas fluorescens (Treatments: T2: N, T6: N+T, T7: N+SA, T8: N+P, T9: N+T+SA, T10: $\mathrm{N}+\mathrm{P}+\mathrm{SA}, \mathrm{T} 11: \mathrm{N}+\mathrm{P}+\mathrm{T}, \mathrm{T12}: \mathrm{N}+\mathrm{P}+\mathrm{T}+\mathrm{SA} ; \mathrm{N}$ : Nematode, T: Trichoderma viride, SA: Salicylic acid, P: Pseudomonas fluorescens). Each number is a mean of four replications in two years.

The greatest increase in plant growth was obtained in $\mathrm{Cv}$. Falat $\mathrm{CH}$ treated with $P$. fluorescens CHAO followed by SA. Fresh weights of shoots were higher in nematode-free plants in all cultivars compared to both $M$. incognita-infested plants and the above-mentioned treatments. The results showed that combined inoculation of fungi, bacteria and SA caused significant reductions $(P \leq 0.01)$ in fresh weight of root $(0.6 \%$, $1 \%, 1 \%$ and $1.6 \%)$, dry weight of root $(1.3 \%$, $2 \%, 0.9 \%$ and $0.9 \%)$ in all cultivars and fresh weight of shoots $(0.5$ and 0.8$)$ in two cultivars (Gina VF and Falat $\mathrm{CH}$ ); plant length (5.9\%, 3.7\%, $7.7 \%$ and $2.2 \%)$, dry weight of shoots $1.75 \%, 2.24 \%, 4.6 \%$ and $2 \%$ ) in all cultivars and fresh weight of shoots $(0.8 \%, 2 \%$ and $0.1 \%$ ) in three cultivars of tomato (Falat $\mathrm{CH}$, Falat 111 and Karoon) increased; galling $(81 \%, 68 \%, 80 \%$ and $83 \%)$, egg mass $(87 \%$, $78 \%, 83 \%$ and $88 \%)$ and reproduction factor $(83 \%, 69 \%, 82 \%$ and $84 \%)$ were reduced compared to the inoculated control in all cultivars (Gina VF, Falat CH, Falat 111 and Karoon, respectively) (Figure 1, Figure 2, Figure 3 and Table 1).

The data indicated that chemical inducer (salicylic acid), in combination with $T$. viri$d e$ and $P$. fluorescens $\mathrm{CHAO}$, stimulated plant response and increased plant growth especially in susceptible cultivars. Inoculation with the $M$. incognita race 2 caused significant reduction $(P \leq 0.01)$ in plant length $(25 \%)$, fresh weight of shoots $(45 \%)$ and roots $(23 \%)$ of tomato cv. Gina VF $(P \leq 0.01)$ in comparison to the uninoculated control (Table 1). The nematode infection caused $31 \%$ reduction in plant length, $52 \%$ in fresh weight of shoot and $30 \%$ in root fresh weight of cv. Falat $\mathrm{CH}$. The cv. Falat 111 exhibited significant decreases in any of the plant parameters (length (34\%), fresh weights of shoots $(49 \%)$ or roots $(27 \%)$ at $P \leq 0.01)$. In the cv. Karoon decreases in plant length (27\%), fresh weight of shoots (54\%) and roots (49\%) were recorded. Soil treatments with $T$. viri- 
de, P. fluorescens and foliar spray of SA gave the greatest recovery of the plant length and dry weight of shoots in all cultivars and in shoot fresh weigh in three cultivars (Falat $\mathrm{CH}$, Falat 111 and Karoon) compared to uninoculated control. The maximum reduction in the numbers of host root galls and egg masses was observed in Karoon cultivar representing the most susceptible cultivar.

According to growing characteristics assessments, the cultivar Gina VF, artificially inoculated with $2000 \mathrm{~J}_{2}$ of root-knot nematode, had the highest root fresh weight, shoot fresh weight, shoot dry weight and length. Thus, this cultivar can be characterized as relatively tolerant. The lowest root fresh weight, shoot fresh and dry weight, shoot length and the maximum number of galls were counted in the cultivar Karoon that was the most susceptible cultivar. In the case of two cultivars, Falat $\mathrm{CH}$ and Falat 111, the Falat 111 had a greater number of galls and higher reproductive factor but its growth characters were less than Falat $\mathrm{CH}$.

\section{Discussion}

Biological control of soil-borne plant pathogens and nematodes using biocontrol microorganisms is a potential non-chemical means in crop protection (Stirling, 1991).

Treatment of the soil with salicylic acid, $P$. fluorescens and $T$. viride resulted in a reduction in the galls and egg mass number of $M$. incognita. Similar results were obtained by other researchers. Trichoderma spp. has been reported to produce chitinases into the culture (Chet and Baker, 1981), which might help the inhibition of egg hatching. Dos Santos et al. (1992) reported Trichoderma harzianum as an effective egg parasite of $M$. incognita; the fungus was able to grow on the egg surface and penetrate the egg shell. In a study by Naserinasab et al. (2011), treatment of the soil with the T. harzianum B1 or salicylic acid resulted in a reduction in the galls, eggs and egg masses of $M$. javanica. Application of T. harzianum, T. hamatum or $T$. virens has also demonstrated potential to suppress root-knot nematodes (Siddiqui and Shaukat, 2004).

Pseudomonas fluorescens was one of the effective agents in reducing $J_{2}$ population and prevented the formation of galls on tomato roots. Similar results have been reported (Siddiqui and Shaukat, 2003; Ali et al., 2002). Siddiqui et al. (2006) found that there is a direct relation between the production of $\mathrm{HCN}$ by $P$. fluorescens $\mathrm{CHAO}$ and mortality of the nematode. Akhtar et al. (2013) suggested that the inoculation with $P$. fluorescens increases the root and shoot length of black gram (Vigna mungo L.) infected with M. incognita. Khan and Haque (2011) reported the greatest plant growth and biomass of tobacco after treatment with $P$. fluorescens compared with T. harzianum and two nematicides.

Our results confirm the findings of Gharabadiyan et al. (2012) sustaining Gina as tolerant cultivar and Karoon as susceptible cultivar, while Falat 111 is similarly tolerant to Falat $\mathrm{CH}$. The combined treatment of the soil with $T$. viride, $P$. fluorescens $\mathrm{CHAO}$ and the chemical inducer salicylic acid clearly improved nematode control of the root-knot nematode $M$. incognita race 2 . In addition, they stimulate plant response and increase plant growth. The study suggests that there is considerable potential for exploiting SA, $P$. fluorescens, and $T$. viride for the management of root-knot nematodes particularly in susceptible cultivars of tomato.

\section{Literature Cited}

Abad, P., Favery, B., Rosso M. and Castagnone-Sereno, P. 2003. Root-knot nematode parasitism and host response: molecular basis of a sophisticated interaction. Molecular Plant Pathology, 4: 217-224.

Akhtar, A., Hisamuddin, R. and Abbasi Sharf. 2013. Study on Black Gram (Vigna mungo L.) Infected with Meloidogyne incognita under the Influence of Pseudomonas fluorescens, Bacillus subtilis and Urea. Journal of Plant Pathology Microbiology, 4: 202.

Ali, N.I., Siddiqui, I.A., Shaukat, S.S. and Zaki, M.J. 2002. Nematicidal activity of some strains of Pseudomonas spp. Soil Biology and Biochemistry, 34: 1051-1058. 
Chet, I. and Baker, R. 1981. Induction of suppressiveness to Rhizoctonia solani in soil. Phytopathology, 70: 994-998.

Dos Santos, M.A., Ferraz, S. and Muchovez J.J. 1992. Evaluation of 20 species of fungi from Brazil for biocontrol of Meloidogyne incognita race-3. Nematropica, 22: 183-192.

Gharabadiyan, F., Jamali, S., Ahmadiyan yazdi, A. and Eskandari A. 2012. Source of resistance to root-knot nematode (Meloidogyne javanica) in tomato cultivars. Journal of Agricultural Technology, 8(6): 2011-2012.

Gugino, B.K., Ludwig, J.W. and Abawi G.S. 2008. An on-farm bioassay for assessing Meloidogyne hapla infestations as a decision management tool. Crop Protection, 27: 785-791.

Hallmann, J., Quadt-Hallmann, A., Miller, W.G., Sikora, R.A. and Lindow, S.E. 2001. Endophyte colonization of plants by biocontrol agent Rhizobium etli G12 in relation to Meloidogyne incognita infection. Phytopathology, 91(4):415-422.

Hartman, K.M. and Sasser, J.N. 1985. Identification of Meloidogyne species on the basis of differential host test and perineal pattern morphology. Pp. 69-77. In: An Advanced Treatise on Meloidogyne. Vol. 2. Methodology (Barker, K.R., Carter, C.C., Sasser, J.N., eds.). North Carolina State University Graphics, Raleigh, USA, 223pp.

Hussey, R.S. and Barker, K.R. 1973. A comparison of methods of collecting inocula of Meloidogyne spp. including a new technique. Plant Disease Reporter, 57: 1025-1028.

Hussey, R.S. and Janssen G.J.W. 2002. Root-Knot. Nematodes: Meloidogyne species. In: Plant Resistance to Parasitic Nematodes (Starr, J.L., Bridge, J., Cook, R., eds.). CABI Publishing, Walling ford, UK, 258p.

Khan, M.R. and Haque, Z. 2011. Soil application of Pseudomonas fluorescens and Trichoderma harzianum reduces root-knot nematode, Meloidogyne incognita, on tobacco. Phytopathology Mediterranea, 50: 257-266.

Khan, M.R., Khan, S.M., Mohiddin, F.A. and Askary, T.H. 2007. Effect of certain phosphate-solublizing bacteria on root-knot nematode disease of mungbean. In: First International Meeting on Microbial Phosphate Solubilizers (Velazuaz, E., Rodriguez, B, ed.). Springer-Verlag, Vienna.

Meyer, S.L.F., Roberts, D.P., Chitwood, D.J., Carta, L.K., Lumsden, R.D. and Mao, W. 2001. Application of Burkholderia cepacia and Trichoderma virens, alone and in combinations, against Meloidogyne incognita on bell pepper. Nematropica, 31: 75-86.

Nandy, B., Kundu, K., Banerjee, N. and Babu, S.P.S. 2003. Salicylic acid induced suppression of $\mathrm{Mel}$ oidogyne incognita infestation of okra and cowpea. Nematology, 5: 742-752.
Naserinasab, F., Sahebani, N. and Etebarian, H.R. 2011. Biological control of Meloidogyne javanica by Trichoderma harzianum B1 and salicylic acid on Tomato. African Journal of Food Science, 5(3): 2765- 280

Sahebani, N. and Hadavi, N. 2008. Biological control of the root-knot nematode Meloidogyne javanica by Trichoderma harzianum. Soil Biology and Biochemistry, 40: 2016-2020.

Sharon, E., Bar-Eyal, M., Chet, I., Herra-Estrella, A., Kleified, O. and Spigel, Y. 2001. Biological control of the root-knot nematode Meloidogyne javanica by Trichoderma harzianum. Phytopathology, 91: 687- 693.

Siddiqui, I.A. and Shaukat, S.S. 2003. Suppression of root-knot disease by Pseudomonas fluorescens CHAO in tomato: importance of bacterial secondary metabolite, 2, 4- diacetylpholoroglucinol. Soil Biology and Biochemistry, 35: 1615 $-1623$.

Siddiqui, I.A. and Shaukat, S.S. 2002. Mixtures of plant disease suppressive bacteria enhance biological control of multiple tomato pathogens. Biology and Fertility of soils, 36: 260- 268.

Siddiqui, I.A. and Shaukat, S.S. 2004. Trichoderma harzianum enhances the production of biocontrol of Meloidogyne javanica by Pseudomonas fluorescens in tomato. Letters in Applied Microbiology, 38: 169-175.

Siddiqui, I.A., Shaukat, S.S., Sheikh, I.H. and Khan, A. 2006. Role of cyanide production by Pseudomonas fluorescens $\mathrm{CHAO}$ in the suppression of rootknot nematode, Meloidogyne javanica in tomato. Microbiology and Biotechnology, 22: 641-650.

Stirling, G.R. 1991. Biological control of plant parasitic nematodes. CAB International, Wallingford, UK. 282 PP.

Taylor, D.P. and Netscher, C. 1974. An improved technique for preparing perineal pattern of Meloidogyne spp. Nematologica, 20: 268.

Whipps, J.M. 2001. Microbial interactions and biocontrol in the rhizosphere. Journal Experess. Botanical, 52: 487-511.

Zhang, S., Moyne, A.L., Reddy, M.S. and Kloepper, J.W. 2002. The role of salicylic acid in induced systemic resistance elicited by plant growth promoting rhizobacteria against blue mold of Tobacco. Biological Control, 25: 288-296.

Received: 16 June 2015; Accepted: 21 December 2015 


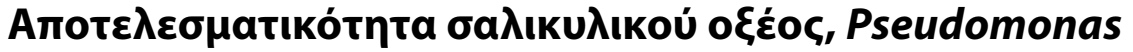

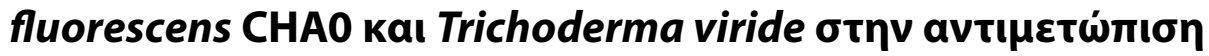

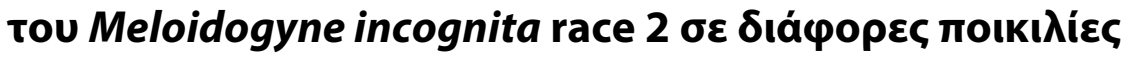 тouátac
}

\author{
L. Esfahani, S. Jamali, A. Saeedizadeh kaı H. Pedramfar
}

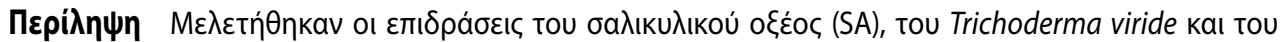

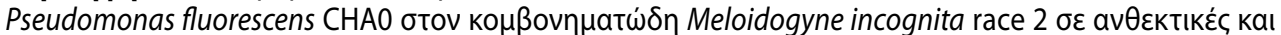

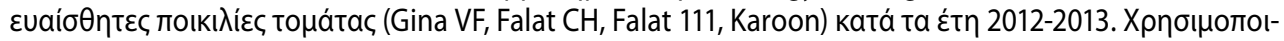

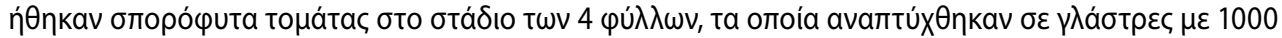

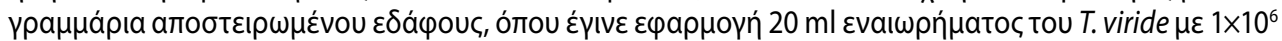

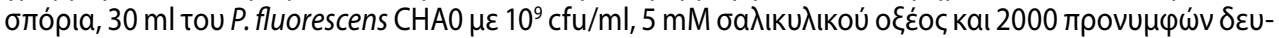

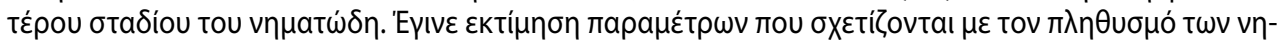

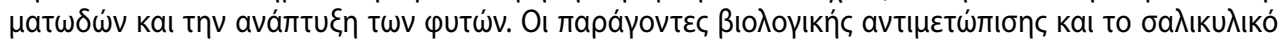

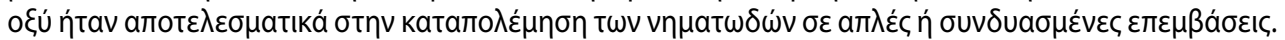

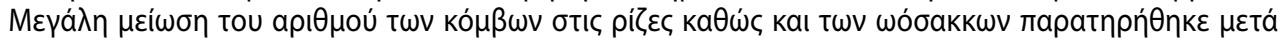

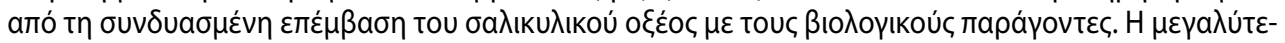

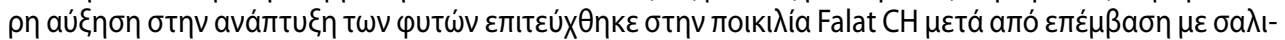

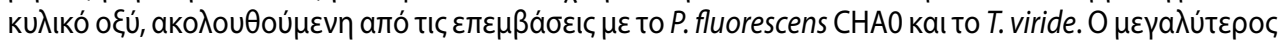

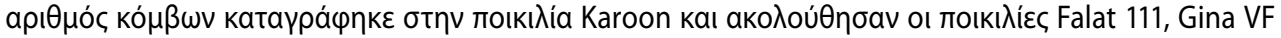

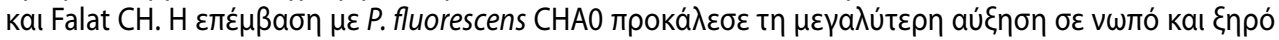

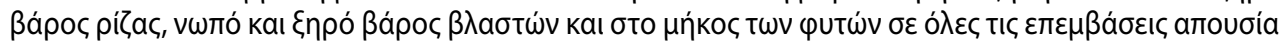

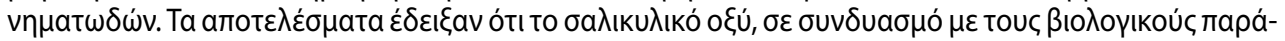

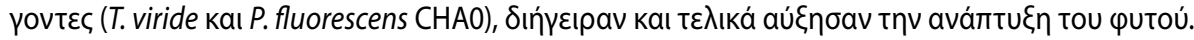

Hellenic Plant Protection Journal 9: 35-43, 2016 